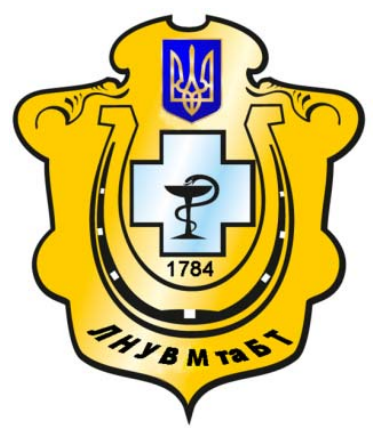

Науковий вісник Львівського національного університету ветеринарної медицини та біотехнологій імені С.3. Гжицького

Scientific Messenger of Lviv National University of Veterinary Medicine and Biotechnologies named after S.Z. Gzhytskyj

doi:10.15421/nvlvet7005

ISSN 2413-5550 print

ISSN 2518-1327 online

$\underline{\text { http://nvlvet.com.ua/ }}$

УДК 619:577.1:619:612.015.3:636.2.053

\title{
Метаболічні процеси в рубці та продуктивний ефект у телят за дії йонофору
}

\author{
O.C. Возна, О.І. Заяць \\ seniv.olga.inbox@gmail.com
}

\begin{abstract}
Львівський національний університет ветеринарної медицини та біотехнологій імені С.3. Гжицького, вул. Пекарська, 50, м. Львів, 79010, Україна
\end{abstract}

Функиї ииклу трикарбонових кислот і циклічного процесу синтезу жирних кислот можливі тільки за умов нормального обміну вуглеводів.Тому важливо знати природу нормального стану метаболізму у рубиі і причини його порушень, а також володіти знаннями, щьб вчасно і вміло впливати екзогенними факторами. Серед останніх особливого значення набуває метаболічна інженерія, яка, иляхом конструювання масштабів і швидкості каскаду основних реакиій перетворень відповідних поєднань субстратів та інших ефекторів, дозволяє одержувати від тварин високий якісний і продуктивний ефект.

У статті наведено експериментальні дані щодо впливу антибіотичної кормової добавки монензину на метаболічні процеси в рубиі телят та їі продуктивний ефект.Отримані результати досліджень метаболізму вуглеводів зміманими популяиіями мікроорганізмів рубия жуйних тварин за дії добавки йонофорурозширюють існуючі відомості про ії роль 6 засвоєнні поживних речовин рачіону, а також доповнюють дані про особливості впливу на інтермедіарний обмін $i$ продуктивний ефект екзогенних факторів субстратно-ерготропного комплексу, що, в кінцевому підсумку, дозволяє конструювати суттєве прискорення процесів анаболізму і досягнення високих рівнів продуктивності.

Проведеними дослідженнями встановлено,що у ростучих телят, особливо при переході на рослинну дієту, добавки йонофору істотно впливають на рубцево-інтермедіарний метаболізм.

Згодовування піддослідним телятам антибіотичної кормової добавки монензину в дозі 0,5 г/кг живої маси в день проявляе відчутну дію на метаболічні прочеси в рубиі, особливо під час привчання тварин до рослинних кормів та в подальші періоди їх згодовування. Ця дія проявлясться, передовсім, у зміні молярного співвідношення ЛЖК (підвищення молярної частки пропіонату за рахунок зниження ачетату), а також у зростанні середньодобових приростів на 10,4\% (1037 проти 939 г).

Ключові слова: метаболізм, антибіотичні речовини, монензин, телята, рубець, прирости.

\section{Метаболические процессы в рубце и продуктивный эффект в телят за действия йонофора}

\author{
О.Е. Возна, О.И. Заяц \\ seniv.olga.inbox@gmail.com
}

Львовский национальный университет ветеринарной медицины и биотехнологий имени С.3. Гжицкого, ул. Пекарская, 50, г. Львов, 79010, Украина

Функиии цикла трикарбоновых кислот и ичклического процесса синтеза жирных кислот возможны только в условиях нормального обмена углеводов. Поэтому важсн знать природу нормального состояния метаболизма в рубие и причины его нарушений, а также обладать знаниями, чтобы вовремя и умело влиять экзогенными факторами. Среди последних особое значение приобретает метаболическая инженерия, которая путем конструирования масштабов и скорости каскада основных реакичий преобразований соответствующих сочетаний субстратов и других эффекторов, позволяет получать от животных высокий качественный и производительный эффект.

\section{Citation:}

Vozna, O., Zayats, O. (2016). Metabolic processes in the rumen and productive effect in calves for action ionophore. Scientific Messenger LNUVMBT named after S.Z. Gzhytskyj, 18, 3(70), 21-25. 
В статье приведены экспериментальные данные о влиянии антибиотической кормовой добавки монензину на метаболические проиессы в рубце телят и ее продуктивный эффект. Полученные результаты исследований метаболизма углеводов смешанными популяциями микроорганизмов рубца жвачных животных за действия добавки йонофора расширяют сущчествуюшие сведения о ее роли в усвоении питательных вещчеств рациона, а также дополняют данные об особенностях влияния на интермедиарный обмен и продуктивный эффект экзогенных факторов субстратно-эрготропного комплекса, что, в конечном итоге, позволяет конструировать существенное ускорение анаболических и достижения высоких уровней производительности.

Проведенными исследованиями установлено, что в растущих телят, особенно при переходе на растительную диету, добавки йонофора существенно влияют на рубцово-интермедиарньй метаболизм.

Скармливания подопытным телятам антибиотической кормовой добавки монензина в дозе 0,5 г/кг живой массы в день проявляет ошутимое воздействие на метаболические процессы в рубце, особенно во время приучения животных к растительным кормам и в последуюшие периоды их скармливания. Это действие проявляется, прежде всего, в изменении молярного соотношения ЛЖК (повышение молярной доли пропионата за счет снижения ацетата), а также в росте среднесуточных приростов на 10,4\% (1037 против 939 г).

Ключевые слова: метаболизм, антибиотические вещуества, монензин, телята, рубец, приросты.

\title{
Metabolic processes in the rumen and productive effect in calves for action ionophore
}

\author{
O. Vozna, O. Zayats \\ seniv.olga.inbox@gmail.com
}

\begin{abstract}
Lviv national university of veterinary medicine and biotechnologies named after S. Gzhytskyj, Pekarska Str., 50, Lviv, 79010, Ukraine
\end{abstract}

Functions tricarboxylic acid and a cyclic fatty acid synthesis process is only possible under normal carbohydrate metabolism. It is therefore important to know the nature of the normal state of metabolism in the rumen and the reasons for its violations, and have the knowledge and skill in time to influence exogenous factors. Among the latter is particularly important metabolic engineering that by constructing the scale and speed of the cascade of reactions major transformations appropriate combinations of substrates and other effectors, yields on high-quality animals and productive effect.

The article presents experimental data on the effect of antibiotic feed additive monensin on metabolic processes in the rumen of calves and its productive effect. The results of carbohydrate metabolism studies with mixed populations of microorganisms rumen of ruminant animals of the additive ionophore expand the existing information about its role in the assimilation of nutritious diet substances, as well as complementary data on the features of influence on of intermediate exchange and productive effect of exogenous factors substrate-ergotropic complex that, in ultimately, it allows the construction of a significant acceleration of anabolic and achieve high levels of performance.

Research evidence that growing calves, especially when switching to vegetarian diet, supplements ionophore significant effect on scar of intermediate metabolism.

Feeding calves antibiotic feed additive monensin at a dose of $0.5 \mathrm{~g} / \mathrm{kg}$ body weight per day, showing a measurable impact on the metabolic processes in the rumen, especially during the habituation of animals to the vegetation and in subsequent periods of feeding. This effect is primarily a change in the molar ratio of VFA (increase the molar proportion of propionate at the expense of acetate), and the average daily gain in growth by 10.4\% (1037 against $939 \mathrm{~g}$ ).

Key words: metabolism, antibiotic substances, monensin, calves, rumen,weight gains.

\section{Вступ}

На сучасному етапі ведення тваринництва великий інтерес викликає застосування антимікробних речовин (Hennig et al., 1986; Vojtjuk, 1995; Gonchar, 2001). Проаналізувавши дані із 300 дослідів із застосуванням 70 мг хлортетрацикліну або окситетрацикліну на тварину в день,вчений D. Tuschy (1978) зробив висновок, що ці добавки збільшують прирости на 9\% і знижують витрати корму на 8\% (Kurylov and Krotkova, 1971). У США 60\% всього поголів'я худоби, що відгодовується, одержує тетрацикліни. До цього слід додати, що у худоби, відгодовуваної 3 мінімумом витрат грубих кормів, часто виникають абсцеси печінки. Але при добавках тетрациклінів кількість ї знижується (Piatkowski, 1975; Kmet' et al., 1990). Виясняючи механізм дії антибіотиків пеніциліну, еритроміцину, хлорамфеніколу і ін., було встановлено зниження $\mathrm{N} \cdot \mathrm{NH}_{3}$ у рубцевій рідині на $35-50 \%$. Тому на даний час позитивний ефект від добавок антибіотиків у концентровані корми при відгодівлі худоби не викликає сумнівів.

Застосування таких антимікробних кормових добавок як йонофори, макроліди, кормові антибіотики тощо сприяє збільшенню приростів на $8-17 \%$ i знижує витрати корму на $10-12 \%$. Наприклад, у США, завдячуючи цим добавкам, протягом року можна було вивільнити близько 800 тис. га посівної площі під зернові та сою. Інші підрахунки свідчать, що у цій країні економічний ефект від застосування антибіотичних речовин складає 2,1 млрд. доларів в рік (Kurylov and Krotkova, 1971; Marounek et al., 1991).

Відомо, що рубцева мікробна популяція здатна інтенсивно зброджувати всі різновиди вуглеводів, які використовуються в живленні жуйної тварини. Порівняно $з$ крохмалем, вона більше ніж у 2 рази продукує ЛЖК при ферментації геміцелюлози. Відносно більше їх продукує вона і при метаболізаціїпектину та целюлози. Цікаво, що при ферментації крохмалю най- 
менше продукується $\mathrm{C}_{2}$. Більше ацетату утворюється iз целюлози i найбільше - iз пектину. Пропіонату найбільше продукується із крохмалю. Подібне (але на нижчому рівні) спостерігається і при аналізі продукції $\mathrm{C}_{4}$. Певна субстратна залежність виявляється і для $\mathrm{C}_{5}$. Такі результати збігаються 3 даними літератури (Davletova, 1974; Kmet' et al., 1990; Leskovych, 1990; Marounek et al., 1991; Kalachnjuk et al., 1991; Ljubec'ka, 2000; Marounek et al., 2001). Вони важливі при визначенні стратегії планування заходів щодо кількісноякісного живлення жуйної тварини з метою одержання від неї максимально бажаної продукції. Суттєву роль тут можуть відіграти екзогенні ерготропні фактори, до яких відносять кишкові стабілізатори та регулятори мікробного метаболізму у рубці (Kurylov and Krotkova, 1971; Kalachnjuk, 1981; Marounek, 1989). Перед усім, це стосується таких антимікробних кормових добавок як йонофори (Kurylov and Krotkova, 1971; Gulyyj and Mel'nychuk, 1978; Marounek et al., 1991).

3 літературних джерел відомо, що деякі антибіотичні кормові добавки - йонофори - інгібують розвиток грампозитивних бактерій у шлунково-кишковому тракті (Kurylov and Krotkova, 1971). Серед них, у світовій практиці ведення тваринницької галузі, найбільш поширеною визнано монензин. I хоча у Великобританії та Німеччині вже понад 20 років з метою зниження проносів, витрат корму на одиницю приросту та підвищення продуктивних якостей ростучих телят використовують такі антибіотичні кормові добавки, як авопарцин, бацитрацин, флавоміцин, віржініаміцин, нітровин у складі замінників молока і концентратів (Marounek et al., 1991), проте питання згодовування йонофорного антибіотикамонензину на сьогоднішній день залишається ще відкритим.

Тому метою наших досліджень було вивчити вплив добавки йонофорумонензину на рубцевий метаболізм і прирости живої маси телят в процесі їх росту і формування якостей жуйної тварини.

\section{Матеріал і методи досліджень}

Дослідження проводились у ДП ДГ «Оброшине» Пустомитівського району Львівської області на двох групах клінічно здорових телят української чорнорябої породи. Годівлю телят здійснювали згідно рекомендованих норм (ВАСХНІЛ, 1985). Накладання фістул на рубець телят виконано у 20-денному віці. Для біохімічних досліджень вміст рубця брали через 2 години після ранкової годівлі.

Вивчали вплив добавки йонофорумонензину на рубцевий метаболізм і прирости живої маси телят в процесі їх росту i формування якостей жуйної тварини, тобто починаючи 3 початкової ваги 52,3 кг і до досягнення 225 кг.

Монензин згодовували разом з рідкими і твердими кормосумішами в дозі 0,5 мг на 1 кг живої маси тварини. Телята до 36-денного віку мали молочну дієту, а далі поступово їх привчали до поїдання концентратів, сухого трав'яного борошна та кукурудзяного силосу. Контрольна група телят (18 бичків) не одержувала антибіотик, а дослідній групі (18 бичків) згодовували його у вищевказаній дозі.

$\mathrm{У}$ вмістимому рубця визначали динаміку рівня $\mathrm{pH}$ за допомогою платинових електродів по Жакобу, летких жирних кислот (ЛЖК) - паровою дистиляцією в апараті Маркгама 3 наступним титруванням; індивідуальних низькомолекулярних карбонових кислот (С2 - ацетату, С3 - пропіонату, C4 - бутирату та ін.) - на газовому хроматографі Chrom-5 3 колонкою 91,8, заповненою Inerton AW (10\% Reopelex 400); N·NH3 - неслеризацією 3 наступною спектрофотометрією за мікрометодом Г.І.Калачнюка i iн. (Kalachnjuk, 1981); лактату - за методикою M.Hohorst.

Статистичну обробку отриманих результатів здійснювали за допомогою програми MicrocalOrigin (Version:5). Порівняння двох мінливих величин проводили на основі показника вірогідності різниці «t» (критерій Ст'юдента). Відмінність між величинами вважали статистично вірогідною, якщо ймовірність різниці Р була меншою 0,05 (*), 0,01 (**) i $0,001(* * *)$.

\section{Результати та їх обговорення}

Із даних, одержаних у наших дослідженнях на ростучих телятах видно, що використання йонофорного антибіотика монензину може мати важливе науково-практичне значення. Результати дослідження представлені у табл. 1 і 2 .

3 наведених даних видно, що згодовування монензину в дозі 0,5 мг на 1 кг живої маси ростучим телятам знижує в рубцевім вмісті $\mathrm{pH}$ і вміст ацетату та підвищує кількість утвореногопропіонату (табл. 1). Однак, це ще не проявляє відповідної дії на рубцевоінтермедіарний метаболізм, щоб підвищити прирости живої маси (табл. 2). Більш відчутна дія йонофору на рубцевий метаболізм спостерігається у періоди привчання телят до рослиннихкормів та при повному переведенні їх на рослинну дієту.

Так, під час привчання виявляється ще й вірогідне збільшення молярного відсотку валеріату при достовірному зниженні метаболічнихіндексів $\mathrm{C}_{2} / \mathrm{C}_{3}$ та NG/GR. Майже теж саме ( а також ще й зниження лактату) в рубці відмічається і впродовж всього періоду живлення на рослинній дієті. Ці чіткі та тривалі зміни у обмінних процесах супроводжуються підвищенням середньодобових приростів живої маси телят. Саме за цей період було одержано найвищі прирости тварин контрольної групи (939 г), a iз згодовуванням монензину вони стають ще вищими (1037 г). Міжгрупова різниця - статистично вірогідна і складає 98 г, тобто - 10,4\%.

Отже, з допомогою йонофорної кормової добавки - монензину можна суттєво впливати на рубцевий метаболізм і прирости живої маси ростучих телят. 
Таблиия 1

Параметри рубцевого метаболізму у ростучих телят за умов згодовування йонофору-монензину $(M \pm \mathbf{m} ; \mathbf{n}=\mathbf{1 8})$

\begin{tabular}{|c|c|c|c|c|c|c|}
\hline \multirow{2}{*}{ Параметри } & \multirow{2}{*}{$\Gamma \mathrm{T}$} & \multicolumn{5}{|c|}{ Етапи досліджень ${ }^{2}$ ) } \\
\hline & & 1 & 2 & 3 & 4 & 5 \\
\hline $\mathrm{pH}$ & $\begin{array}{l}\text { К } \\
\text { Д }\end{array}$ & $\begin{array}{l}6,01 \pm 0,24 \\
5,92 \pm 0,30\end{array}$ & $\begin{array}{c}6,21 \pm 0,34 \\
5,71 \pm 0,20^{*}\end{array}$ & $\begin{array}{c}5,78 \pm 0,31 \\
5,49 \pm 0,26^{*}\end{array}$ & $\begin{array}{l}6,14 \pm 0,04 \\
5,74 \pm 0,12\end{array}$ & $\begin{array}{l}6,75 \pm 0,37 \\
6,29 \pm 0,14\end{array}$ \\
\hline $\mathrm{N} \cdot \mathrm{NH}_{3}$, мг/л & $\begin{array}{l}\text { К } \\
\text { Д }\end{array}$ & $\begin{array}{c}87 \pm 33 \\
75 \pm 48\end{array}$ & $\begin{array}{l}341 \pm 126 \\
325 \pm 122\end{array}$ & $\begin{array}{l}378 \pm 39 \\
379 \pm 78\end{array}$ & $\begin{array}{l}236 \pm 51 \\
267 \pm 44\end{array}$ & $\begin{array}{l}131 \pm 54 \\
136 \pm 66\end{array}$ \\
\hline Лактат, мМ & $\begin{array}{l}\text { К } \\
\text { Д }\end{array}$ & $\begin{array}{l}0,76 \pm 0,34 \\
0,30 \pm 0,13\end{array}$ & $\begin{array}{l}3,82 \pm 1,39 \\
3,29 \pm 0,68\end{array}$ & $\begin{array}{c}0,54 \pm 0,5 \\
0\end{array}$ & $\begin{array}{c}3,17 \pm 0,31 \\
0,77 \pm 0,42 *\end{array}$ & $\begin{array}{c}2,69 \pm 0,70 \\
1,49 \pm 0,51^{*}\end{array}$ \\
\hline Сума ЛЖК, мМ & $\begin{array}{l}\text { К } \\
\text { Д }\end{array}$ & $\begin{array}{l}88,7 \pm 13,9 \\
89,2 \pm 27,8\end{array}$ & $\begin{array}{l}89,7 \pm 21,7 \\
99,1 \pm 24,0\end{array}$ & $\begin{array}{c}132,4 \pm 15 \\
147 \pm 33\end{array}$ & $\begin{array}{c}134,6 \pm 2,0 \\
98 \pm 12 *\end{array}$ & $\begin{array}{l}113 \pm 31 \\
121 \pm 28\end{array}$ \\
\hline $\begin{array}{c}\mathrm{C}_{2}, \\
\text { моль } \%\end{array}$ & $\begin{array}{l}\text { К } \\
\text { Д }\end{array}$ & $\begin{array}{l}55,1 \pm 2,1 \\
55,8 \pm 2,7\end{array}$ & $\begin{array}{c}55,3 \pm 3,1 \\
50,3 \pm 2,7^{*}\end{array}$ & $\begin{array}{l}52,2 \pm 1,0 \\
48,8 \pm 2,8\end{array}$ & $\begin{array}{c}49 \pm 2,7 \\
47,1 \pm 2,5\end{array}$ & $\begin{array}{l}54,8 \pm 3,9 \\
52,4 \pm 3,2\end{array}$ \\
\hline $\begin{array}{c}\mathrm{C}_{3}, \\
\text { моль } \%\end{array}$ & $\begin{array}{l}\text { К } \\
\text { Д }\end{array}$ & $\begin{array}{l}24,9 \pm 2,3 \\
25,6 \pm 2,8\end{array}$ & $\begin{array}{c}27,7 \pm 1,1 \\
31,8 \pm 2,2 *\end{array}$ & $\begin{array}{c}31,2 \pm 2,5 \\
34,3 \pm 1,2^{*}\end{array}$ & $\begin{array}{l}25,0 \pm 2,4 \\
29,0 \pm 2,8\end{array}$ & $\begin{array}{c}27,3 \pm 3,5 \\
31,7 \pm 3,5^{*}\end{array}$ \\
\hline $\begin{array}{c}\mathrm{C}_{4}, \\
\text { моль } \%\end{array}$ & $\begin{array}{l}\text { К } \\
\text { Д }\end{array}$ & $\begin{array}{c}10,4 \pm 1,0 \\
11,5 \pm 1,3\end{array}$ & $\begin{array}{c}9,6 \pm 1,0 \\
10,4 \pm 1,3\end{array}$ & $\begin{array}{c}9,8 \pm 1,2 \\
11,1 \pm 1,6\end{array}$ & $\begin{array}{c}15,0 \pm 1,6 \\
12,1 \pm 1,9^{*}\end{array}$ & $\begin{array}{l}13,7 \pm 1,6 \\
12,7 \pm 2,3\end{array}$ \\
\hline $\begin{array}{c}\mathrm{iC}_{5}, \\
\text { моль } \%\end{array}$ & $\begin{array}{l}\text { К } \\
\text { Д }\end{array}$ & $\begin{array}{l}2,7 \pm 1,1 \\
2,7 \pm 1,5 \\
\end{array}$ & $\begin{array}{l}2,3 \pm 0,7 \\
1,1 \pm 0,1 \\
\end{array}$ & $\begin{array}{l}0 \\
0 \\
\end{array}$ & $\begin{array}{l}3,2 \pm 2,1 \\
4,6 \pm 2,2\end{array}$ & $\begin{array}{l}0 \\
0 \\
\end{array}$ \\
\hline $\begin{array}{c}\mathrm{C}_{5}, \\
\text { моль } \%\end{array}$ & $\begin{array}{l}\mathrm{K} \\
\text { Д } \\
\end{array}$ & $\begin{array}{l}6,9 \pm 0,9 \\
7,1 \pm 1,1 \\
\end{array}$ & $\begin{array}{c}5,1 \pm 1,2 \\
7,7 \pm 1,7^{*}\end{array}$ & $\begin{array}{l}6,8 \pm 1,2 \\
5,8 \pm 1,6\end{array}$ & $\begin{array}{l}7,8 \pm 2,0 \\
7,2 \pm 1,6\end{array}$ & $\begin{array}{l}4,2 \pm 1,8 \\
3,2 \pm 1,3 \\
\end{array}$ \\
\hline $\mathrm{C}_{2} / \mathrm{C}_{3}$ & $\begin{array}{l}\text { К } \\
\text { Д }\end{array}$ & $\begin{array}{l}2,21 \pm 0,27 \\
2,17 \pm 0,29\end{array}$ & $\begin{array}{c}1,99 \pm 0,13 \\
1,58 \pm 0,14^{*}\end{array}$ & $\begin{array}{c}1,67 \pm 0,15 \\
1,40 \pm 0,1\end{array}$ & $\begin{array}{l}1,96 \pm 0,25 \\
1,62 \pm 0,25\end{array}$ & $\begin{array}{c}2,0 \pm 0,43 \\
1,65 \pm 0,38\end{array}$ \\
\hline $\left.\mathrm{NG} / \mathrm{GR}^{3}\right)$ & $\begin{array}{l}\text { К } \\
\text { Д }\end{array}$ & $\begin{array}{l}2,60 \pm 0,32 \\
2,54 \pm 0,33\end{array}$ & $\begin{array}{c}2,43 \pm 0,15 \\
1,98 \pm 0,18^{*}\end{array}$ & $\begin{array}{c}2,07 \pm 0,17 \\
1,76 \pm 0,11 *\end{array}$ & $\begin{array}{l}2,23 \pm 0,42 \\
2,07 \pm 0,25\end{array}$ & $\begin{array}{l}2,01 \pm 0,6 \\
1,81 \pm 0,6\end{array}$ \\
\hline
\end{tabular}

Примітка: ГТ - групи телят; $\left.{ }^{1}\right)-\mathrm{K}$ - контроль, Д - згодовування йонофору 0,5 мг/кг живої маси; ${ }^{2}$ )-1- дослідження до початку експерименту, 2- дослідження на молочній дієті, 3- дослідження під час привчання до рослинних кормів, 4 і 5дослідження на рослинній дієті; ${ }^{3}$ ) - індекс відношення неглюкогенних до глюкогенних кислот за формулою Јеnsen $\mathrm{NG} / \mathrm{GR}=\left(\mathrm{C}_{2}+2 \mathrm{C}_{4}+\mathrm{C}_{5}\right) /\left(\mathrm{C}_{3}+\mathrm{C}_{5}\right) ; * \mathrm{P}<0,05$

Таблиия 2

Продуктивний ефект від згодовування йонофору ростучим телятам $(\mathbf{M} \pm \mathbf{m} ; \mathbf{n}=\mathbf{1 8})$

\begin{tabular}{|c|c|c|}
\hline \multirow{2}{*}{ Параметри } & \multicolumn{2}{|c|}{ Групи телят } \\
\hline & $\mathrm{K}$ & Д \\
\hline Тривалість досліду (днів) & 181 & 181 \\
\hline $\begin{array}{c}\text { Жива маса: } \\
\text { на початку досліду (кг) } \\
\text { на кінець молочного періоду (кг) } \\
\text { на кінець досліду (кг) } \\
(\%)\end{array}$ & $\begin{array}{c}53,2 \pm 11,2 \\
76,8 \pm 11,3 \\
213,0 \pm 12,0 \\
100,0\end{array}$ & $\begin{array}{l}52,3 \pm 12,4 \\
75,6 \pm 10,7 \\
225,9 \pm 8,2 \\
106,1\end{array}$ \\
\hline $\begin{array}{c}\text { СДП до кінця молочного } \\
\text { періоду (г) } \\
(\%)\end{array}$ & $\begin{array}{c}657 \pm 24,2 \\
100,0\end{array}$ & $\begin{array}{c}647 \pm 13,1 \\
99,0\end{array}$ \\
\hline $\begin{array}{c}\text { СДП від кінця молочного } \\
\text { періоду (г) } \\
(\%) \\
\end{array}$ & $\begin{array}{c}939 \pm 16,1 \\
100,1\end{array}$ & $\begin{array}{c}1037 \pm \\
10,6^{*} \\
110,4 \\
\end{array}$ \\
\hline $\begin{array}{c}\text { СДП за } 181 \text { день (г) } \\
(\%)\end{array}$ & $\begin{array}{c}883 \pm 15,2 \\
100,0\end{array}$ & $\begin{array}{c}959 \pm 9,3 \\
108,6\end{array}$ \\
\hline
\end{tabular}

Примітка: К - контрольна; Д - дослідна; СДП -

середньодобові прирости; ${ }^{*} \mathrm{P}<0,05$

\section{Висновки}

Згодовування ростучим телятам монензину в дозі 0,5 мг/кг живої маси в день проявляє відчутну дію на метаболічні процеси в рубці, особливо під час привчання тварин до рослинних кормів та в подальші періоди їх згодовування. Ця дія проявляється, передовсім, у зміні молярного співвідношення ЛЖК (підвищення молярної частки пропіонату за рахунок зниження ацетату), а також у зростанні середньодобових приростів на 10,4\% (1037 проти 939 г).

Перспективи подальших досліджень. Доцільно продовжити дослідження 3 вивчення метаболічних процесів у рубці жуйних тварин за дії йонофорної кормової добавки монензину.

\section{Бібліографічні посилання}

Vojtjuk, O.A. (1995). Peretvorennja formiatu i jogo vplyv na okremi metabolichni procesy u rubci: avtoref. dys. na zdobuttja nauk. stupenja kand. biol. nauk: spec: 03.00.04. Biohimija. L'viv. 22 (in Ukrainian).

Gonchar, M.V. (2001). Shljahy energozabezpechennja i detoksykacii' u metylotrofnyh drizhdzhiv ta i'h skerovana modyfikacija $\mathrm{z}$ metoju stvorennja novyh fermentatyvnyh i biosensornyh analitychnyh system: avtoref. dys. na zdobuttja nauk. stupenja doktorabiol. nauk: spec: 03.00.04 Biohimija. Kyi'v. 35 (in Ukrainian).

Hennig, A. [i dr.]. (1986). Jergotropiki: Reguljatory obmena veshhestv i ispol'zovanija kormov sel'skohozjajstvennymi zhivotnimi. Moskva: Agropromizdat (in Russian).

Kurylov, N.V., Krotkova, A.P. (1971). Fyzyologyja y byohymyja pyshhevarenyja zhvachnyyh. Moskva. Kolos (in Russian).

Piatkowski, B. (1975). NährstoffVerwertung beim Wiederkäuer. Jena: FischerVerlag. 424. 
Kmet', V., Baran, M., Kalachnyuk, G.I. (1990). Rumen ecosystem manipulation of calves and lambs by microbial preparations. Bratislava: Veda. 112.

Marounek, M., Peter, O., Kalačniuk, G. (1991). Použiti probiotikuhospodarskychzvirat. Naš chov. 7, 330-332.

Gulyyj, M.F., Mel'nychuk, D.A. (1978). Rol' uglekyslotyy v reguljacyy obmena veshhestv ugeterotrofnyyh organyzmov. Kyev: Naukova dumka (in Ukrainian).

Davletova, L.V. (1974). Byologyja razvytyja organov pyshhevarenyja zhvachnyyh y vsejadnyyh zhyvotnyyh. Moskva: Nauka (in Russian).

Kalachnjuk, G.Y., Marounek, M., Savka, O.G., Shymunek, Y. (1991). Metabolyzm polysaharydov v rubcovoj srede pod dejstvyem yonofornogo antybyotyka monenzyna. S.-h. Byologyja. 6, 89-96 (in Ukrainian).

Leskovych, B.M. (1990). Osobennosty azotystogo y uglevodnogo obmena $\mathrm{u}$ teljat pry skarmlyvanyy rost stymulyrujushhyh dobavok: avtoref. dys. na soyskanyja nauch. stepenykand. byol. nauk : spec: 03.00.13 Fyzyologyja. L'vov (in Ukrainian).

Ljubec'ka, T.V. (2000). Osoblyvosti metabolichnoi' adaptacii' teljat na rannih etapah postnatal'nogo rozvytku ta shljahy korekcii' vyjavlenyh porushen': avtoref. dys. na zdobuttja nauk. stupenja doktoravet. nauk: spec: 03.00.04 Biohimija. Kyi'v (in Ukrainian).

Marounek, M., Savka, O., Kalachnyuk, G. (2001). Effect of $\mathrm{C}_{8}$ and $\mathrm{C}_{10}$ fatty acids of growtn of rumen and intestinal bacteria. Sci. Mes. Lviv St. Acad. Vet. Med. After S.Z. Gzhytskyi, 3(3), 119-124 (in Ukrainian).

Marounek, M. [et al.] (1989). The effect of monensin on in vitro utilization of lactate in the rumen contents. Arch. Anim. Nutr. 6, 489-496.

Kalachnjuk, G.Y. (1981). Mykrometod uskorennogo opredelenyja koncentacyy ammyaka $\mathrm{V}$ rubcovoj zhydkosty. Nauchn.-tehn. Bjull. Ukr. nauchn.yssledov. yn-t fyzyol. y byohym. s.-h. zhyvotnyh. 3(3), 24-25 (in Ukrainian).

Стаття надійшла до редакиії 1.10.2016 